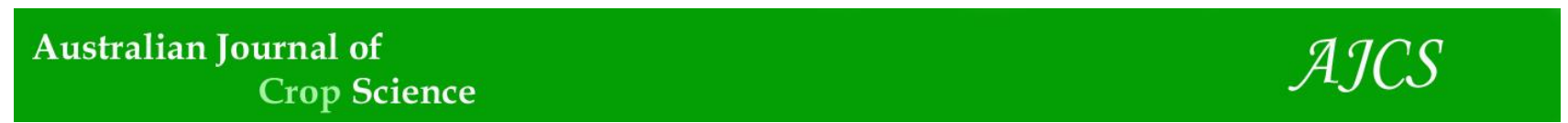

AJCS 15(07):1074-1080 (2021)

ISSN:1835-2707

doi: 10.21475/ajcs.21.15.07.p3254

\title{
Biochemical and physiological changes in conilon coffee (Coffea canephora) grown under different levels of irradiance
}

\author{
Daniel Soares Ferreira ${ }^{1 *}$, Ramon Amaro de Sales ${ }^{1}$, José Francisco Teixeira do Amaral ${ }^{2}$, João Marcos Soares \\ Ferreira ${ }^{1}$, Luan Peroni Venancio ${ }^{1}$, Wilian Rodrigues Ribeiro ${ }^{2}$, Marcelo Antonio Tomaz ${ }^{2}$, Diogo de Souza \\ Baltazar Catem², Morgana Scaramussa Gonçalves², Núbia Pinto Bravin ${ }^{1}$
}

${ }^{1}$ Federal University of Viçosa, Department of Agronomy, Av. Peter Henry Rolfs, s/n - university campus, Viçosa - MG, 36570-900, Minas Gerais, Brazil

${ }^{2}$ Federal University of Espirito Santo, Department of Agronomy, High University, s/n, Guararema, AlegreES, 29500-000, Espírito Santo, Brazil

ORCIDs: ${ }^{10000-0003-3428-4964 ;{ }^{2} 0000-0002-1872-7182 ;{ }^{3} 0000-0002-2603-9048 ;{ }^{4} 0000-0002-3198-9187 ;}$ ${ }^{5} 0000-0002-5544-8588 ;{ }^{6} 0000-0003-0711-7669 ;{ }^{7} 0000-0002-9228-7541 ;{ }^{9} 0000-0003-3724-5477 ;{ }^{10} 0000-$ 0001-9993-4644.

\section{Corresponding author: danielccaufes@gmail.com}

\begin{abstract}
Modern agriculture values the most sustainable and dynamic means of production, which can be promoted through the association between coffee and tree components, aiming at the best use of the land. However, within our understanding of the physiological and biochemical behaviors of the coffee tree, the irradiance limiting conditions are crucial to maximize the potential gains generated in these systems. In this sense, the objective of this study was to evaluate the effects of different levels of irradiance restriction on the physiological and biochemical characteristics of two genotypes of Conilon coffee. The experiment was conducted in a $2 \times 3$ factorial scheme, corresponding to two Conilon coffee clones and three levels of light intensity restriction (0, 30 and $50 \%)$, in a randomized block design with four replications. The synthesis of total chlorophyll b and the leaf $\mathrm{N}$ content of the genotypes CL6 and CL12 increased with the reduction of light. On the other hand, there was a reduction in the levels of carbohydrates, amino acids and phenols with the reduction of light intensity. Restricted levels of irradiance caused different changes in the physiological and biochemical characteristics of the studied genotypes, showing genetic divergences between them.
\end{abstract}

Keywords: Secondary metabolism; Shaded cultivation; Climate change.

Introduction

Coffee farming represents a significant portion of the Brazilian economy, being important in socioeconomic development, generating jobs both directly and indirectly (Quartezani et al., 2018; Quartezani et al., 2019, Ferreira et al., 2021). With widespread planting (mainly in the Brazilian states of Minas Gerais, Espírito Santo, Bahia, São Paulo and Rondônia), in an area of $1,812,800$ hectares it provided a production of approximately 49 million bags of coffee in 2019 (ICO, 2018; CONAB, 2019).

Espírito Santo is the second largest coffee producing state in Brazil and produces the largest volume of Conilon coffee (Coffea canephora Pierre ex A. Froehner) in the country, exerting significant influence on the socioeconomic and agro-industrial aspects of the region (CONAB, 2019; Vitória et al., 2019). Although this culture is originally from tropical regions of Africa and is typical of understory (DaMatta et al., 2007), cultivation in the state of Espírito Santo is predominantly in full sun.
Although luminosity is an important environmental resource, responsible for the luminous reactions of photosynthesis and directly impacting plant growth and development, excessive luminous intensity can be harmful to culture (DaMatta et al., 2018). Consortium crops or agroforestry systems (SAFs), by allowing moderate shading, minimize problems related to high irradiance. These consortia are defined in phytotechnical practices that are important in mitigating potential adverse effects on coffee arising from ongoing climate change, and may contribute to maintaining the sustainability of coffee production (Pezzopane et al., 2007; Charbonnier et al., 2017).

The shading emission by these systems not only affects the distribution of solar radiation in the canopy of the plant, but also helps in maintaining a favorable microclimate, maintaining greater soil moisture and the harmful effects caused by wind and temperature (DaMatta et al., 2001). Thus, as the main commercial coffee species (C. arabica $\mathrm{L}$. 
and $C$. canephora Pierre and $A$. Froehner) evolved in shaded environments, as ongoing rapid climate changes will be intensified by high levels of irradiance (DaMatta, 2018), which can lead to physiological and biochemical disorders, ultimately impacting crop yield.

In this context, physiological and biochemical changes can occur in response to different irradiances. Among these changes, we can mention changes in the level of chlorophylls, cellular respiration, nitrogen allocation and synthesis of secondary metabolites (Evans and Poorter, 2001; Lu et al., 2015; Slot et al., 2019). In addition, changes in the specific leaf area and leaf thickness can contribute to changes in the carbon balance, making it important to assess the magnitude of these responses in different genotypes, seeking better acclimatization capacity.

Although the study of luminous intensity is something widely disseminated in the literature in different cultures, little is known about the physiological and biochemical effects in Conilon coffee genotypes, making it important to elucidate the behavior. Thus, the objective of the present study is to evaluate the effects of different light intensities on the physiological and biochemical characteristics of two Conilon coffee genotypes.

\section{Results}

There were significant interactions $(p<0.05)$ between the different luminosities and clones for photosynthetic pigments and levels of amino acids in the leaves of Conilon coffee (Tables 1). As no interactions were observed between genotypes and shading factors, the levels of $\mathrm{N}$, carbohydrates, phenols and proteins (Tables 1) were assessed separately.

For Clone Vitória 6 (CL6), no differences were identified between the levels of luminosity in relation to the chlorophyll a index (Table 2). On the other hand, Clone Vitória 12 (CL12) showed a difference with $50 \%$ of shading, in which the chlorophyll index a was reduced by $23 \%$ in relation to CL12 at full sun.

When evaluating the levels of chlorophyll, a of the genotypes (Table 2), it was observed that the shading levels of 0 and $30 \%$ did not promote statistical differences. However, a difference in the response of chlorophyll to the $50 \%$ level of shading was observed, since the response of CL6 was greater than that of CL12. For the chlorophyll b index, CL12 showed lower values than CL6 when grown in full sun. However, the $30 \%$ level of shading caused the rapid response of $\mathrm{CL} 12$, with an increase in the synthesis of chlorophyll b, which caused the chlorophyll $b$ index to exceed that of CL6.

Total chlorophyll (Table 3) in CL12 leaves increased with the highest level of shading, while the highest total chlorophyll index in CL6 was displayed under 30\% shading. For the chlorophyll a / b ratio, the reduction was observed with the increase in shading, regardless of the genotype. When grown in full sun, the chlorophyll a / b ratio was higher in CL12 than in CL6. However, in the shading levels of 30 and $50 \%$, the opposite occurred, with a greater relationship in CL6. There is also a significant difference between treatments for total chlorophyll, however for chlorophyll a for the level of irradiance restriction of $0 \%, \mathrm{CL} 6$ was greater than CL12, while for the levels of $30 \%$ and $50 \%$, CL12 was greater. greater than CL6.
Under $50 \%$ of shading, the leaf $\mathrm{N}$ content (Table 4) increased $23 \%$ when compared to plants under full sun. Carbohydrates and phenols showed a similar response pattern, opposite to that of $\mathrm{N}$, with their levels reduced under shading $(20.14 \%$ and $14.38 \%$ respectively).

CL12 had a higher $\mathrm{N}$ content, while phenols and carbohydrates were higher in CL6 (Table 5). In comparison with CL12, the levels of carbohydrates and phenols produced by CL6 were higher in 25 and $33 \%$ of the samples, respectively. The proteins did not differ according to the levels of shading or genotypes.

For luminosity levels (Table 6), the amino acid contents of CL6 and CL12 were higher for plants grown in full sun. There was a difference between genotypes when subjected to shading of $30 \%$, in which the amino acid content of CL12 was higher than that of CL6. However, this difference was no longer observed under $50 \%$ shading.

\section{Discussion}

\section{Shading effects}

The luminosity restriction considerably increased the chlorophyll $b$ and total indices (Tables 2 and 3) for both genotypes studied, which was consistent with most studies found in the literature (Dai et al., 2009; Baldi et al., 2012; Zhou et al., 2017; Santos Junior et al., 2019). Plants that developed in shaded environments tend to invest more in pigments capable of increasing light absorption. Although the number of chloroplasts per unit of leaf area reduces in leaves submitted to low irradiance, their chloroplasts have a higher chlorophyll content (Fu et al., 2012).

The reduction observed in the chlorophyll $a / b$ ratio (Table 3 ) in shaded leaves is mainly due to an increase in chlorophyll $b$, which has been proven to have a greater capacity to absorb scattered light under shading conditions and improve the absorption efficiency of blue light (Huang et al., 2016; Liu et al., 2018). Therefore, this reduction may be linked to the acclimatization of the photosynthetic system of the plant, which maximizes the absorption of light.

Coffee plants submitted to shading had increased leaf $\mathrm{N}$ contents (Table 4). This suggests that the $\mathrm{N}$ content exceeds the physiological requirements in low-light environments, which may result in luxury consumption (Singh and Singh, 2001; Tripathi and Raghubanshi, 2014; Liu et al., 2018). Therefore, due to lower energy expenditures in the cellular maintenance of shaded plants, the greater accumulation of $\mathrm{N}$ may occur (Tripathi and Raghubanshi, 2014).

In addition, it was observed in Zostera marina that reductions in energy and available carbohydrates coincide with a decline in nitrate reductase activity, which could reduce the nitrate assimilation capacity, favoring its storage in cell compartments (Touchette and Burkholder, 2000; Peralta et al., 2002). Similar results were found by Bote and Struik (2011), in which they verified higher leaf $N$ contents in coffee trees grown in the shade.

As observed in an experiment conducted by Moraes et al. (2010), Arabica coffee plants grown in the open can exhibit a better growth, with a higher net assimilation rate, which is associated with a higher photosynthetic rate. Therefore, these conditions contribute to a greater amount of leaf carbohydrates (Table 4), especially in Conilon coffee, since these plants survive in higher temperatures and irradiances than Arabica coffee. Plants under a higher light intensity 
Table 1. Summary of the analysis of variance of two conilon coffee genotypes (CV6 and CV12) grown at three different irradiance restriction levels $(0 \%, 30 \%$ and $50 \%)$.

\begin{tabular}{|c|c|c|c|c|c|c|}
\hline \multicolumn{4}{|l|}{ Factors } & \multicolumn{3}{|l|}{ Medium square } \\
\hline $\mathrm{FV}$ & $\mathrm{GL}$ & Chlorop. $a$ & Chlorop. $b$ & Total chlorop & Chlorop a/b & Amino acids \\
\hline Block & 3 & 6.20 & 11.57 & 14.28 & 0.082 & 0.145 \\
\hline Irradiance (I) & 2 & $3.44^{\mathrm{ns}}$ & $161.91 *$ & $114.2^{*}$ & $4.41 *$ & $14.15^{*}$ \\
\hline Genotype (G) & 1 & $9.06^{\mathrm{ns}}$ & $0.015^{\text {ns }}$ & $9.82^{\text {ns }}$ & $0.38 *$ & $1.44^{*}$ \\
\hline interaction $\mathrm{I}^{*} \mathrm{G}$ & 2 & $41.23^{*}$ & $44.58^{*}$ & $39.23^{\text {ns }}$ & $2.21 *$ & $4.87^{*}$ \\
\hline Resudue & 15 & 7.60 & 4.39 & $10.41^{*}$ & 0.022 & 0.101 \\
\hline \multirow[t]{2}{*}{ CV (\%) } & & 7.04 & 10.58 & 5.45 & 6.87 & 5.26 \\
\hline & & \multicolumn{5}{|c|}{ Medium square } \\
\hline FV & $\mathrm{GL}$ & $\mathrm{N}$ & Carbohydrates & Phenols & Proteins & \\
\hline Block & 3 & 2.67 & 9.96 & 3.10 & 3.02 & \\
\hline Irradiance (I) & 2 & $45.50 *$ & 125.59* & $10.73^{*}$ & $94.95^{*}$ & \\
\hline Genotype (G) & 1 & $18.55^{*}$ & $1270.2^{*}$ & $188.16^{*}$ & $53.10 *$ & \\
\hline interaction $I^{*} \mathrm{G}$ & 2 & $7.38^{\mathrm{ns}}$ & $25.23^{\mathrm{ns}}$ & $1.64^{\mathrm{ns}}$ & $120.96^{\mathrm{ns}}$ & \\
\hline Resudue & 15 & 2.42 & 24.87 & 0.837 & 40.22 & \\
\hline CV (\%) & & 6.76 & 7.99 & 4.3 & 22.78 & \\
\hline
\end{tabular}

*Significant $\mathrm{F}$ at $5 \%$ probability level, "Ns" not significant.

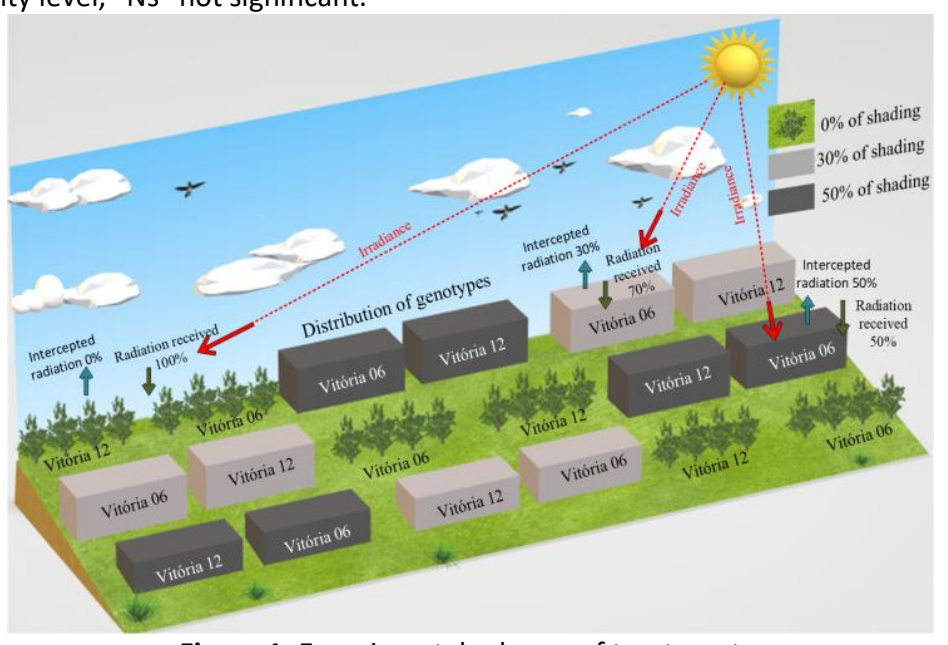

Figure 1. Experimental scheme of treatments.

Table 2. Chlorophyll $a$ and $b$ indices in the leaves of Conilon coffee genotypes submitted to different shading levels.

\begin{tabular}{|l|l|l|l|l|l|l|}
\hline \multirow{2}{*}{ Genotype } & $0 \%$ & $30 \%$ & $50 \%$ & $0 \%$ & $30 \%$ & $50 \%$ \\
\hline CL6 & $39.7 \mathrm{aA}$ & $40.5 \mathrm{aA}$ & $40.4 \mathrm{aA}$ & $17.4 \mathrm{bA}$ & $19.8 \mathrm{abB}$ & $22.3 \mathrm{aA}$ \\
\hline CL12 & $43.9 \mathrm{aA}$ & $41.9 \mathrm{aA}$ & $34.1 \mathrm{bB}$ & $12.0 \mathrm{bB}$ & $23.4 \mathrm{aA}$ & $23.9 \mathrm{aA}$ \\
\hline
\end{tabular}

Means followed by the same letter do not statistically differ from each other (uppercase in columns and lowercase in rows) according to Tukey's 5\% $(\mathrm{p}<0.05)$ probability test.

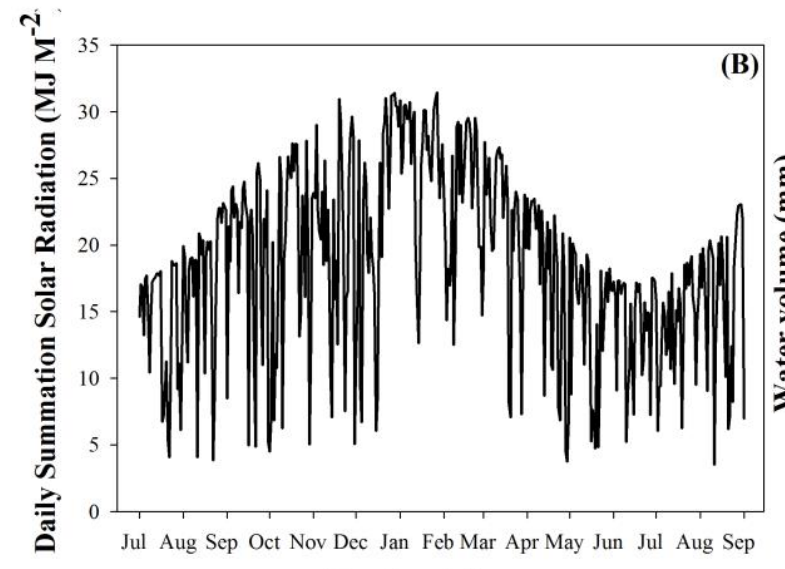

Months of the year

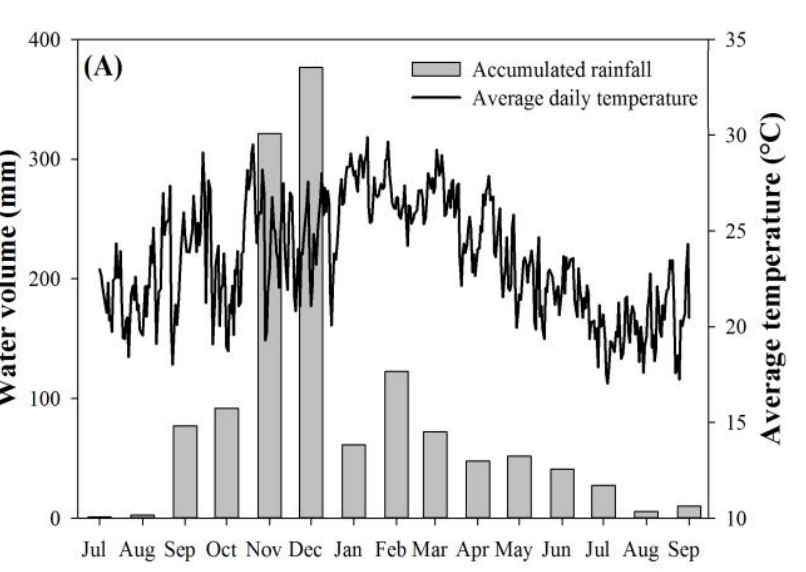

Monthly cumulative rainfall

Figure 2. Precipitation, average monthly air temperature (A), and solar radiation balance (B) from August 2013 to July 2014 in the municipality of Alegre - ES 
Table 3. Total chlorophyll index and chlorophyll $a / b$ ratio in the leaves of Conilon coffee genotypes submitted to different shading levels

\begin{tabular}{|l|l|l|l|l|l|l|}
\hline \multirow{2}{*}{ Genotype } & \multicolumn{2}{l}{ Total chlorophyll } & \multicolumn{5}{|l}{ Chlorophyll a/b ratio } \\
\cline { 2 - 8 } & $0 \%$ & $30 \%$ & $0 \%$ & $2.3 \mathrm{cB}$ & $2.1 \mathrm{abA}$ & $1.8 \mathrm{bA}$ \\
\hline CL6 & $56.4 \mathrm{bA}$ & $60.3 \mathrm{abA}$ & $62.7 \mathrm{aA}$ & $3.8 \mathrm{aA}$ & $1.7 \mathrm{bB}$ & $1.4 \mathrm{cB}$ \\
\hline CL12 & $53.5 \mathrm{bA}$ & $64.1 \mathrm{aA}$ & $58.1 \mathrm{bA}$ &
\end{tabular}

Means followed by the same letter do not statistically differ from each other (uppercase in columns and lowercase in rows) according to Tukey's $5 \%(\mathrm{p}<0.05)$ probability test.

Table 4. $\mathrm{N}$ content, carbohydrates, phenols, and proteins in the leaves of Conilon coffee genotypes submitted to different shading levels

\begin{tabular}{|c|c|c|c|c|}
\hline Shading (\%) & $\mathrm{N}(\mathrm{g} / \mathrm{kg})$ & Carbohydrates $(\mathrm{g} / \mathrm{kg})$ & Phenols (g/kg) & Proteins (g/kg) \\
\hline 0 & $20.5 c$ & $67.1 \mathrm{a}$ & $23.0 \mathrm{a}$ & $26.3 \mathrm{a}$ \\
\hline 30 & $23.2 \mathrm{~b}$ & $60.3 b$ & $21.3 \mathrm{~b}$ & $25.1 \mathrm{a}$ \\
\hline 50 & $25.3 \mathrm{a}$ & $60.1 \mathrm{~b}$ & $20.1 \mathrm{~b}$ & $39.0 \mathrm{a}$ \\
\hline
\end{tabular}

Averages followed by the same letter do not statistically differ from each other at the $5 \%$ probability level $(p<0.05)$ according to the Tukey test.

Table 5. $\mathrm{N}$ content, carbohydrates, phenols, and proteins in the leaves of Conilon coffee genotypes submitted to different shading levels

\begin{tabular}{|l|l|l|l|l|}
\hline Genotype & $\mathrm{N}(\mathrm{g} / \mathrm{kg})$ & Carbohydrates $(\mathrm{mg} / \mathrm{g})$ & Phenols $(\mathrm{mg} / \mathrm{g})$ & Proteins $(\mathrm{mg} / \mathrm{g})$ \\
\hline CL6 & $22.1 \mathrm{~b}$ & $69.0 \mathrm{a}$ & $24.2 \mathrm{a}$ & $26.3 \mathrm{a}$ \\
\hline CL12 & $23.9 \mathrm{a}$ & $55.1 \mathrm{~b}$ & $18.3 \mathrm{~b}$ & $29.0 \mathrm{a}$ \\
\hline
\end{tabular}

Averages followed by the same letter do not statistically differ from each other at the $5 \%$ probability level $(p<0.05)$ according to the Tukey test.

Table 6. Amino acid contents in the leaves of Conilon coffee genotypes submitted to different shading levels

\begin{tabular}{|c|c|c|c|}
\hline \multirow[t]{2}{*}{ Genotype } & \multicolumn{3}{|c|}{ Amino acids (g/kg) } \\
\hline & $0 \%$ & $30 \%$ & $50 \%$ \\
\hline CL6 & $7.77 \mathrm{aA}$ & $4.22 \mathrm{cB}$ & $5.42 \mathrm{bA}$ \\
\hline CL12 & $7.39 \mathrm{aA}$ & $6.51 \mathrm{bA}$ & $4.98 \mathrm{cA}$ \\
\hline
\end{tabular}

Means followed by the same letter do not statistically differ from each other (uppercase in columns and lowercase in rows) according to Tukey's 5\% $(p<0.05)$ probability test.

Table 7. Average photosynthetically active radiation, available at each level of shading and standard deviation measured with the aid of the light meter model LI-250

\begin{tabular}{|l|l|l|}
\hline $\begin{array}{l}\text { Irradiance Restriction } \\
(\%)\end{array}$ & $\begin{array}{l}\text { Photosynthetically active radiation } \\
\left(\mu \mathrm{mol} \text { photons } \mathrm{m}^{-2} \mathrm{~s}^{-1}\right)\end{array}$ & Actual irradiance restriction (\%) \\
\hline 0 & $1188.56 \pm 10,43$ & 0 \\
\hline 30 & $786.89 \pm 39,55$ & 33.8 \\
\hline 50 & $622.22 \pm 23,68$ & 47.3 \\
\hline
\end{tabular}

generally produce more carbohydrates, which is a fundamental characteristic that reflects the differences in species concerning growth and survival under different environmental stresses (Farhadi et al., 2013; Hosseini et al., 2014). The increase in the carbohydrate production of plants in full sun (Table 4) may indicate a higher carbon accumulation for amino acid synthesis (Table 6), thus the leaf $\mathrm{N}$ stock is used for amino acid production, which is corroborated by the lower leaf $\mathrm{N}$ content (Table 4). According to Deng et al. (2013), from the carbohydrates synthesized by the plant and nitrogen assimilated from the soil, amino acids can be synthesized. Moreover, although no statistical differences were observed concerning the protein levels, the plants in full sun presented lower values than those in $50 \%$ shade. This suggests the possible degradation of proteins by these plants, contributing to the much higher increases in amino acids of plants in full sun (Table 6).

The phenol levels were higher in coffee plants in full sun, which is an expected response, since plants in full sun are more susceptible to oxidative processes and require greater protection. According to Ilić and Fallik (2017), vegetables accumulate a number of phenolic compounds and other antioxidants as a protective measure against high irradiance and ultraviolet light. Therefore, the different levels of irradiance promote distinct physiological and biochemical changes. This response was also observed by Rodríguez-López et al. (2013), who observed better responses concerning the physiological performance of coffee bushes shaded in the morning, when grown in a severe tropical environment.

\section{Effects of genotypes}

Under 50\% shading, CL12 had a lower chlorophyll $a$ index compared to that of CL6 (Table 2). However, this did not affect the total chlorophyll of the genotypes, as both genotypes were equal at all shading levels, which reveals that there was a greater investment by CL12 in chlorophyll $b$. This can be observed in the chlorophyll $a / b$ ratio (Table 3 ), in which CL12 presented a 
lower ratio than CL6. As observed by Rodríguez-López et al. (2013), photosynthetic acclimatization in response to variations in luminosity depends upon the genotype and nature of the luminous environment.

In full sun, a higher chlorophyll $b$ index was observed for CL6 compared to CL12. However, under 30\% shading, CL12 presented a rapid response, with an increased chlorophyll $b$ index that surpassed that of CL6 (Table 2). Therefore, the physiological plasticity of CL12 is greater, and small environmental changes are sufficient to modify its physiological characteristics. This higher acclimatization in response to the environment can be observed in the chlorophyll $a / b$ ratios, in which shading caused CL12 to have lower results. At the leaf level, acclimatization can be expressed through morpho-anatomical and physiological adjustments in response to changes in the luminous environment (Evans and Poorter, 2001; Lusk et al., 2008).

The carbohydrate and phenol contents of CL12 were lower than those of CL6, while the leaf $\mathrm{N}$ content (CL12) was higher (Table 5). This shows that the accumulation capacity of these compounds is different and strongly influenced by species or cultivar. Genetic divergences among the genotypes of the clonal variety 'Vitória Incaper 8142' have been observed by several authors in studies related to nutritional efficiency (Covre et al., 2013; Machado et al., 2016; Berilli et al., 2020). However, for the leaf $N$ content, Covre et al. (2013) and Machado et al. (2016) found no difference between genotypes 6 and 12 .

Regarding the phenol contents in Table 4, the results allow deductions regarding the ability of CL6 to present a higher chance of survival in the field in stressful situations. This is due to the fact that phenolic compounds are secondary metabolites, containing numerous varieties of compounds, such as simple flavonoids, phenolic acids, and complex flavonoids, which usually perform a protective function in plants (Babbar et al., 2014; Lin et al., 2016; Sales et al., 2018). In addition, the carbohydrate content can also contribute to the greater survival of these plants in the field. According to Myers and Kitajima (2007), plants that present a higher carbohydrate content under shading conditions can be considered more susceptible to survival in this system.

\section{Materials and Methods}

\section{Study location description}

The experiment was conducted in a Conilon coffee crop with 5 years of cultivation, in the Experimental Area of the Center for Sciences and Agronomic Engineering of the Federal University of Espírito Santo (CCAE-UFES), located 113 meters above sea level in Alegre - ES, Brazil (2045 '48"S, $41031^{\prime} 57$ "W and $250 \mathrm{~m}$ of altitude). The climatic data were obtained at the INMET meteorological station located in the vicinity of the experiment, and the predominant climate was characterized as hot / humid summer and dry winter. Precipitation during winter was $1299.6 \mathrm{~mm}$. Between July 2016 and September 2017, the average temperature was $24.16^{\circ} \mathrm{C}$ (Figure $1 \mathrm{~A}$ ) and the minimum and maximum global radiation values were $1060.16 \mathrm{KJ} \mathrm{m}^{-2}$ month-1 (Figure 1B) in July 2016 and $1916.50 \mathrm{KJ} \mathrm{m}^{-2} \mathrm{~d}-1$ in January 2017, respectively.

\section{Description of treatments and experimental designer}

The experiment was conducted in a $2 \times 3$ factorial scheme, which represented two genotypes of Conilon coffee (Clone Vitória 06 and Clone Vitória 12) and three levels of shading (0 (full sun), 30 and $50 \%$ irradiance restriction), in a randomized block design with four repetitions. Each experimental plot was represented by a plant. The genotypes were selected from the cultivar "Vitória Incaper 8142" according to their agronomic characteristics. The availability of light was altered during the experiment with the use of polyolefin screens with different radiation retention capacities, which were installed in the form of a tunnel to cover the entire plant (Figure 2). The photosynthetically active radiation in the canopy of the plants was determined at each level of shading with the use of the model LI-250 photometer. (Table 7). The measurements were made in clear sky at 12 o'clock on October 21, 2019, thus determining the actual percentage of shading used for each treatment. Throughout the crop cycle, nutritional and phytosanitary management was carried out in accordance with the technical recommendations for Conilon coffee in the state of Espírito Santo (Ferrão et al., 2007).

\section{Determination of chlorophyll}

For the biochemical and physiological analyses, eight leaves of previously marked plagiotropic branches from each plant were used. The leaves were collected at the beginning of the fruit maturation phase. A portable chlorophyll meter (ChlorofilogCFL 1030 (Falker)) was used to determine the chlorophyll index. Subsequently, the leaves were collected, stored in liquid nitrogen, and taken to the laboratory. Here, they were macerated and sieved through a $2.0 \mathrm{~mm}$ mesh. The leaf nitrogen was analyzed using the micro-Kjeldahl method.

\section{Determination of biochemical variables}

The free amino acids were extracted using hot ethanol (98, 80 , and $50 \%$ ) and submitted to centrifugation. The supernatants were collected and separated according to the protein contents. The amino acid determination followed the methodology of Yemm and Cocking (1955). The protein fraction was determined from the precipitate obtained after extraction. Protein dosage was performed according to the method of Goa (1953). The total carbohydrates were determined using the sum of the starch and total soluble sugars (non-structural carbohydrates) contents according to the methodology proposed by Fales (1951).

The determination of the total soluble phenols was performed based on the modified methods of Poorter and Villar (1997). A dilution of the sample was determined from a linearity test, in which $100 \mu \mathrm{L}$ of the hydrophilic phase, resulting from the extraction procedure of the compounds, was diluted in a ratio of $1: 20(\mathrm{v} / \mathrm{v})$ with $80 \%$ ethanol solution. Increments of $50 \mu \mathrm{L}$ of the diluted extract, $450 \mu \mathrm{L}$ of distilled water, $250 \mu \mathrm{L}$ of folin reagent, and $1250 \mu \mathrm{L}$ of $10 \%$ sodium carbonate solution composed the $2 \mathrm{~mL}$ of the reaction. Within 20 minutes, the samples that consisted of phenolic compounds acquired a bluish gray coloration, and the color intensity was directly proportional to the amount of phenol present in the sample.

\section{Statistical analysis}

The samples were submitted to spectrophotometry at a wavelength of $725 \mathrm{~nm}$. From the absorbance, the results were calculated using the standard tannic acid curve as a function of the initial $250 \mathrm{mg}$ mass used in the extraction of the compounds, expressed as a percentage.

Before the analysis of variance, the Shapiro-Wilk and Bartlett tests were used to verify that the assumptions of normality 
of errors and homogeneity of variances were meet, respectively. Then, the data were submitted to the analysis of variance $(p<0.05)$. When the $F$ test was significant, the Tukey test was performed at the $5 \%$ probability level $(p<$ $0.05)$. The entire statistical procedure was performed using the open source program $\mathrm{R}$.

\section{Conclusion}

The shading levels prompted different responses between the genotypes concerning the physiological and biochemical characteristics, thus providing evidence for the existence of possible genetic divergence.

The chlorophyll $b$ synthesis and leaf $\mathrm{N}$ content of genotypes CL6 and CL12 increased with reduced luminosity.

There was a decrease in the levels of carbohydrates, amino acids, and phenols with the reduction in the light intensity of the coffee genotypes studied. Genotype CL6 showed a higher accumulation of carbohydrates and phenols, and may present a higher chance of survival in the field in situations unfavorable to its development.

\section{Acknowledgements}

This work was financially supported by the Espírito Santo Research and Innovation Support Foundation (FAPES), Coordination for the Improvement of Higher Education Personnel (CAPES), National Council for Scientific and Technological Development (CNPq).

\section{References}

Babbar N, Oberoi HS, Sandhu SK, Bhargav VK (2014) Influence of different solvents in extraction of phenolic compounds from vegetable residues and their evaluation as natural sources of antioxidants J Food Sci. 51(10): 2568-2575. Doi: 10.1007 / s13197-012-0754-4.

Baldi P, Muthuchelian K, La Porta N (2012) Leaf plasticity to light intensity in Italian cypress (Cupressus sempervirens L.): adaptability of a Mediterranean conifer cultivated in the Alps. J Photoch Photobio A. 117: 61-69. Doi: 10.1016 / j.jphotobiol.2012.09.006.

Berilli SS, Sales RA, Ribeiro HR, Zooca AAF, Salles RA, Berilli APCG, Costa TS (2020) Foliar fertilization in the propagation of conilon coffee in alternative substrates. International J Agri Natural Res. 47 (1): 58-68. Doi: 10.7764 / ijanr.v47i1.2085.

Bote AD, Struik PC (2011) Effects of shade on growth, production and quality of coffee (Coffea arabica) in Ethiopia. J Hortic Forestry. 3 (11): 336-341.

Brouwer R (1962) Nutritive influences on the distribution of dry matter in the plant. Netherlands J Agr Scie. 10: 361376.

Charbonnier F, Roupsard O, Le Maire G, Guillemot J, Casanoves F, Lacointe A, Clément-Vidal A (2017) Increased light-use efficiency sustains net primary productivity of shaded coffee plants in agroforestry system. Plant, Cell Envir. 40 (8): 1592-1608. Doi: 10.1111 / pce.12964

CONAB Companhia Nacional de Abastecimento. (2019) Acompanhamento de safra brasileira de café, Terceiro levantamento, Brasília. 5 (3): 1-48. Acesso: https://www.conab.gov.br/info-agro/safras/cafe.

Covre AM, Mauri A, Dias M, Partelli F (2013) Crescimento e desenvolvimento inicial de genótipos de café Conilon. J Agroambiente. 7 (2): 193-202. Doi: 10.18227/19828470ragro.v7i2.944
Dai Y, Shen Z, Liu Y, Wang L, Hannaway D, Lu H (2009) Effects of shade treatments on the photosynthetic capacity, chlorophyll fluorescence, and chlorophyll content of Tetrastigma hemsleyanum Diels et Gilg. Envir Exp Bot. 65: 177-182. Doi: 10.1016/j.envexpbot.2008.12.008

DaMatta FM, Avila RT, Cardoso AA, Martins SC, Ramalho JC (2018) Physiological and agronomic performance of the coffee crop in the context of climate change and global warming: A review. J A Food Chem. 66(21): 5264-5274. Doi: 10.1021 / acs.jafc.7b04537.

DaMatta FM, Rena AB (2001) Tolerância do café à seca. In: Zambolim, L. Tecnologias de Produção de Café com Qualidade. $1^{\circ} \mathrm{ed}$. Editora UFV, Viçosa. 4

DaMatta FM, Ronch ICP, Maestr IM, Barros RS (2007) Ecophysiology of coffee growth and production. Braz J Plant Physiol. 19(4): 485-510. Doi: 10.1590/S167704202007000400014.

Deng WW, Fei Y, Wang S, Wan XC, Zhang ZZ, Hu XY (2013) Effect of shade treatment on theanine biosynthesis in Camellia sinensis seedlings. Plant Growth Regulation. 71 (3): 295-299.

Evans J, Poorter H (2001) Photosynthetic acclimation of plants to growth irradiance: the relative importance of specific leaf area and nitrogen partitioning in maximizing carbon gain. Plant Cell Envir. 24(8): 755-767. Doi: 10.1046/j.1365-3040.2001.00724.x.

Farhadi N, Souri MK, Alirezalu A, Moghaddam M (2013) Effect of sowing dates on quantity and quality of castor bean (Ricinus communis L.) under semi-arid condition in Iran. Zeitschrift für Arznei-\& Gewürzpflanzen. 18(2): 72-77.

Ferrão MAG, Ferrão RG, Fonseca AFA, Verdin Filho AC, Volpi PS (2007) Origem, dispersão geográfica, taxonomia e diversidade genética de Coffea canephora. In: Ferrão RG, Fonseca AFA, Bragança SM, Ferrão MAG \& Muner LH. Café conilon. Café conilon. Editora Incaper, Vitoria-ES, 1a ed: 66-91.

Ferreira, DS, Amaral JFT, Pererira LL, Ferreira JMSF, Guarçoni RC, Moreira TR, Oliveira AC, Rodrigues WN, Almeida SLH, Ribeiro WR, Tomaz MA, Castanheira DT, Lima Filho T (2021) Physico-chemical and sensory interactions of arabica coffee genotypes in different water regimes. J Agri Sci. 1-9. 2021.

Fu W, Li P, Wu Y (2012) Effects of different light intensities on chlorophyll fluorescence characteristics and yield in lettuce. Sci Hort. 135: 45-51.

Goa J (1953) A micro biuret method for protein determination, determination of total protein in cerebrospinal fluid. Scandinavian J Clin Labor Invest. 5(3): 218-222. Doi: 10.3109/00365515309094189

Hosseini SMA, Souri MK, Farhadi N, Moghadam M, Omidbaigi $R$ (2014) Changes in glycyrrhizin content of Iranian licorice (Glycyrrhiza glabra L.) affected by different light intensities diameter and ecological conditions. Agri Comm. 2: 27-33.

Huang CJ, Wei G, Jie YC, Xu JJ, Anjum SA, Tanveer M (2016) Effect of shade on plant traits, gas exchange and chlorophyll content in four ramie cultivars. Photosynthetica.54: 390-395. Doi: 10.1007/s11099-016-0186-x

Ilić ZS, Fallik E (2017) Light quality manipulation improves vegetable quality at harvest and postharvest: A review. Envir Exp Botany. 139: 79-90. Doi: 10.1016/j.envexpbot.2017.04.006. 
Lin D, Xiao M, Zhao J, Li Z, Xing B, Li X, Chen H (2016) An overview of plant phenolic compounds and their importance in human nutrition and management of type 2 diabetes. Molecules. 21 (10): 1374. Doi: 10.3390 / moléculas 21101374

Liu JF, Kang FF, Yu AH, Yang WJ, Chang EM, Jiang ZP (2018) Responses of foliar carbohydrates and nutrient status of two distinctive cypress species to shading and nitrogen addition. Glob Ecol Cons, 16: 452. Doi: 10.1016/ j.gecco.2018.e00452.

Lu Y, Zhang M, Meng X, Wan H, Zhang J, Tian J, Yao Y (2015). Photoperiod and shading regulate coloration and anthocyanin accumulation in the leaves of malus crabapples. Plant Cell, Tissue and Organ Culture (РCTOC), 121 (3): 619-632. Doi: 10.1007 / s11240-0150733-3.

Lusk CH, Reich PB, Montgomery RA, Ackerly DD, CavenderBares J. (2008). Why are evergreen leaves so contrary about shade? Trends Ecol Evol. 23(6): 299-303. Doi: 10.1016/j.tree.2008.02.006

Machado LS, Martins LD, Rodrigues WN, Ferreira DS, Côgo AD, Tomaz MA, do Amaral JFT. (2016). Efficiency and response of conilon coffee genotypes to nitrogen supply. Afri J Biotec. 15(35): 1892-1898. Doi: 10.5897 / AJB2016.15558.

Moraes GABK, Chaves ARM, Martins SCV, Barros RS, DaMatta FM (2010) Why is it better to produce coffee seedlings in full sunlight than in the shade? A morphophysiological approach. Photosynthetica. 48 (2): 199-207. Doi: 10.1007/s11099-010-0025-4.

Myers JA, Kitajima K (2007) Carbohydrate storage enhances seedling shade and stress tolerance in a neotropical forest. J Ecol. 95(2): 383-395. Doi: 10.1111/j.13652745.2006.01207.x.

OIC- Organização Internacional de Café (2018) Estatísticas de comércio, 2018.2 Disponível http://www.ico.org/pt/new_historical_p.asp?section=Esta t\%EDstica. Acesso: 27 Fevereiro de 2020.

Peralta G, Pérez-Lloréns JL, Hernández I, Vergara JJ (2002) Effects of light availability on growth, architecture and nutrient content of the seagrass Zostera noltii Hornem. Journal of Experimental Marine Biol Ecol. 269 (1): 9-26. Doi: 10.1016/S0022-0981(01)00393-8.

Pezzopane JRM, Pedro MJ, Gallo PB, de Camargo MBP, Fazuoli LC (2007) Avaliações fenológicas e agronômicas em café arábica cultivado a pleno sol e consorciado com banana'Prata Anã'. Bragantia. 66(4): 701-709. Doi: 10.1590/S0006-87052007000400021.

Poorter H, Villar R (1997) The fate of acquired carbon in plants: chemical composition and construction costs. In: $F$. A. Bazzaz \& J. Grace, Eds., Plant Resource Allocation, Academic Press, San Diego, pp. 39-72.

Quartezani WZ, Sales RA, Berilli SS, Pletsch TA, Rodrigues WP, Campostrini E, Bernado WP, Oliveira EC, Hell LR, Mantoanelli E (2018) Effect of different sources of organic matter added to the substrate on physiological parameters of clonal plants of conilon coffee. Aust J Crop Sci. 12 (08): 1328-1334. Doi: 10.21475 / ajcs.18.12.08.PNE1150.
Quartezani WZ, Sales RA, Pletsch TA, Berilli SS, Mantoanelli E, Hell LR, Oliveira EC, Neves LF, Neves JDC (2019) Effect of different proportions of urban organic compost on Conilon coffee (Coffea canephora) propagation. Aust J Crop Sci. 13 (06): 821-827. Doi: 10.21475 / ajcs.19.13.06.p1313.

Rodríguez-López NF, Cavatte PC, Silva PE. Martins SC, Morais LE, Medina EF, DaMatta FM (2013) Physiological and biochemical abilities of robusta coffee leaves for acclimation to cope with temporal changes in light availability. Physi Plant. 149 (1): 45-55. Doi: 10.1111/ppl.12010.

Sales RA, Sales RA, Santos RA, Quartezani WZ, da Silva Berilli $S$, de Oliveira EC. (2018). Influência de diferentes fontes de matéria orgânica em componentes fisiológicos de folhas da espécie Schinus terebinthifolius Raddi.(Anacardiaceae). Sci Agraria. 19 (1): 132-141. Doi: 10.5380/rsa.v19i1.51511.

Santos Junior A, Freitas F, Santos I, Silva D, Paixão G, Sediyama C (2019) Management Of Commelina benghalensis with Saflufenacil in Shaded Environments. Planta Daninha. 37 (19) 78-88. Doi: 10.1590/s0100-83582019370100051.

Slot M, Krause GH, Krause B, Hernández GG, Winter K. (2019). Photosynthetic heat tolerance of shade and sun leaves of three tropical tree species. Photosy Res. 141 (1): 119-130. Doi: 10.1007/s11120-018-0563-3

Singh A, Singh JS (2001) Comparative growth behaviour and leaf nutrient status of native trees planted on mine spoil with and without nutrient amendment. Annals of Botany. 87 (6): 777-787. Doi: 10.1006/anbo.2001.1414.

Tripathi SN, Raghubanshi AS. (2014). Seedling growth of five tropical dry forest tree species in relation to light and nitrogen gradients. J Plant Ecol, 7 (3): 250-263. Doi: 10.1093/jpe/rtt026.

Touchette BW, Burkholder JM. (2000). Review of nitrogen and phosphorus metabolism in seagrasses. J Exper Marine Bio Ecol. 250 (2): 133-167. Doi: 10.1016/S00220981(00)00195-7.

Vitória YTD, Leite MCT, Delgado RC, Moreira GF, Oliveira ECD, Quartezani WZ, Sales RA (2019) Soil carbon dioxide efflux in conilon coffee (Coffea canephora Pierre ex A. Froehner) plantations in different phenological phases in tropical climate in Brazil. Chil J Agri Rese 79 (3): 366-375. Doi: 10.4067/S0718-58392019000300366.

Yemm EW, Cocking EC, Ricketts RE. (1955). The determination of amino-acids with ninhydrin. Analyst, 80 (948): 209-214.

Zhou Y, Huang L, Wei X, Zhou H, Chen X. (2017). Physiological, morphological, and natomical changes in Rhododendron agastum in response to shading. Plant Grow Regul, 81 (1): 23-30. Doi: 10.1007/s10725-016-0181-z. 